\title{
HUMAN RIGHTS OBLIGATIONS, ESPECIALLY, IN TIMES OF CRISIS
}

\author{
MARÍA JOSÉ AÑÓN*
}

\begin{abstract}
This article is a critical reflection on human rights obligations and the changes that have taken place in their conception and functions, as well as their impact on the protection of human rights - especially in crises. The text is divided into two parts. The first section presents the features that characterise human rights obligations while focusing on the arguments that give them identity and reinforce their binding nature, with human beings as the subjects of rights and beneficiaries of obligations that broaden the responsibility of the obligated states. The second section analyses these obligations in times of crisis, such as the Covid-19 pandemic. Therefore, this piece of research focuses on two significant legal situations based on the relevant elements of obligations: on one hand, it critically reflects on the derogative clauses in obligations, and, on the other hand, reviews the prohibition of regression or dilution of human rights as a guarantee for the maintenance of such obligations.
\end{abstract}

Keywords: Human rights, obligations, collective guarantee obligations, derogation, limitation of rights, obligation of progressivity.

Summary: 1. Introduction. 2. Characteristics of Human Rights Obligations. 2.1. The objective nature of obligations. 2.2. Obligations independent of the principle of reciprocity. 2.3. Collectively guaranteed obligations. 2.4. Obligations arising from mandatory rules. 2.5. Obligations towards people - beneficiaries of obligations. 2.6. Extension of accountability 3. Maintenance Obligations in Times of Crisis. 3.1. Derogation and limitation of rights. 3.2. Prohibition of regressivity. 4. ConCluding Notes.

\section{INTRODUCTION}

This article reflects on the importance of the evolution of the obligations associated with human rights and on the changes that have taken place in their conception and functions, and the repercussions on the protection of human rights - especially during crises. These are periods in which the explanations for justifying the derogation of obligations, the regression of rights, and excesses in rights limitations seem to be growing, and therefore when obligated states have an even greater responsibility in the face of non-compliance.

By examining the characteristics of human rights obligations from the point of view of its practice, we find keys to understand the unfinished evolution towards a universal system of human rights protections within United Nations, which is the focus of this analysis. This set of norms acquired, during its development, its own identity as it created its own legal corpus. Moreover, human rights obligations attained new characteristics that distinguish them from other types of right obligations inherent to public international law. This was the paragon initially used to develop the current human rights system. This does

\footnotetext{
* Full professor of Philosophy of Law, Universitat de València, Spain (mariaj@uv.es).
} 
not mean that the human rights system constitutes a closed circuit in the sense that they would completely and finally exclude the application of the general law, that is, general customary law and general principles of law' as the International Law Commission (2006: 92-93) stresses out, but above all because, as Mégret (2010) points out, this evolution is based 'in the fact that human rights are intrinsically different in nature and belong to a very different history and teleology than general international law'.

The proclamation of the Universal Declaration of Human Rights and the subsequent developments in international human rights law allow us to affirm altogether with Cardona (2016: 132) that we have a system for protecting human rights. ${ }^{1}$ In this system, human rights treaties have a normative value, and rights protection is the responsibility of the international community (which has a legal interest in reacting in the event of serious human rights violations). Cardona explains that to respond to these requirements, the international legal regime has adopted certain features. It is a legal regime of a general nature that is endowed with peremptory norms and general obligations and whose guarantor is the international community.

This is an evolution in progress and it is characterized by clear advances in two directions: on one hand, the determination or establishment of obligations linked to human rights; and on the other hand, the institutional framework for the application and protection of rights, in particular, the identification of human rights violations and the adoption of protective legal decisions.

The relevant sources of knowledge are broad and reflect a field in which contributions of various kinds converge. These include the normative content of treaties, their interpretation and application, the contribution of treaty monitoring bodies and other bodies, the decisions of international courts and tribunals, international organisations, the impact on national jurisdictions, the action of states and other obligated subjects, the growing contribution of various actors such as human rights defenders, academia, organisations, and non-government organisations.

The legal, political, and ethical perspectives on the more conceptual aspects of obligations are also relevant in this itinerary. Although this article is not the place to do an in-depth, I will briefly point out that an initial conception of obligations is linked to the strengthening of the protection system through legal. This is a perspective which, although insufficient, is necessary. The legal regime of human rights is identified, in Medina's words, as 'a system for protecting human dignity that constitutes a true international public order, the maintenance of which must be of interest to all states that participate

\footnotetext{
${ }^{1}$ This work has been carried out within the framework of Project DER2016-78356P 'Transformations in justice. Autonomy, inequality, and exercise of rights' which is part of the National Programme for Research, Development, and Innovation - as well as project PROMETEO2018-156 (Generalitat Valenciana).

A legal corpus consisting of the rights included in the nine United Nations human rights treaties and their protocols, as well as an institutional architecture that includes the committees for each of the treaties, that is, the bodies with the power to control and supervise the fulfilment of human rights by states. Both the rights and the institutional dimension constitute the legal regime of human rights.
} 
in the system' $(2005,209)$. However, the normative theses that encourage associative, cooperative, and political conceptions of rights cannot be ignored (Iglesias 2016). Neither can we ignore a legal perspective based on the legal practice of human rights (Lafont 2020) and oriented towards the extension of responsibility for the violation of human rights, and the recognition of non-state subjects as having a duty, simultaneously and separately, for the possible responsibility of the state according to the specific duties it has in such circumstances (Chodry 2018, 16). We must also recognise supranational and extraterritorial state obligations related to the promotion and respect for rights, and obligations towards non-citizens interpreted in terms of duties towards the international community (Fraser 2008: 222-32, 239, 247, 260).

Thus, I will approach to the topic in two parts. The first part presents those features that characterise human rights obligations. The aim is to understand how the respect, support, and protection of human rights are obligations for all states. A special attention is paid to what reinforces their binding nature and broadens the responsibility of the obligated subjects: the position of the human being as a subject of rights and beneficiary of obligations. The second part analyses these obligations in crises such the Covid-19 pandemic. Based on the relevant elements of obligations, I focus on two significant legal situations: the derogative clauses of obligations and the prohibition of regression. Ultimately, I argue that recognising the evolution of obligations and incorporating these changes into human rights theory helps to test whether these legal situations advance the protection of human rights.

\section{Characteristics OF hUMAN Rights Obligations}

In order to start with the study of the characteristics of human rights obligations, I would like to analyse a text from the Inter-American Court of Human Rights. ${ }^{2}$ It is an advisory opinion that summarises the main theses on human rights obligations and echoes the approach of the European Commission of Human Rights ${ }^{3}$ and clearly expresses an affirmation of human rights obligations. I reproduce the whole paragraph.

29. The Court should emphasise that modern human rights treaties in general, and the American convention, are not multilateral treaties of the traditional type that are concluded based on a reciprocal exchange of rights for the mutual benefit of the contracting states. The purpose of modern human rights treaties is the protection of the fundamental rights of human beings, irrespective of their nationality, both regarding their own state and regarding other contracting states. In adopting these human rights treaties, states submit themselves to a legal order within which they, for

\footnotetext{
${ }^{2}$ Inter-American Court of Human Rights Advisory Opinion OC-2/82 of 24 September 1982 on the effect of reservations on the entry into force of the American Convention on Human Rights (arts. 74 and 75) as requested by the Inter-American Commission on Human Rights $§ 29$.

${ }^{3}$ The European Commission of Human Rights was the competent body to receive complaints and decide on their admissibility and refer them, if necessary, to the European Court of Human Rights, until 1998 when Protocol 11 of the European Convention on Human Rights came into force.
} 
the common good, accept obligations, not in relation to other states, but towards the individuals under their jurisdiction. The special character of these treaties has been recognised, among others, by the European Commission of Human Rights when it stated: 'the obligations assumed by the High Contracting Parties to the (European) Convention are essentially of an objective character, designed to protect the fundamental rights of human beings from violations by the High Contracting Parties rather than to create subjective and reciprocal rights between the High Contracting Parties' ('Austria v. Italy', Application No. 788/60, European Yearbook of Human Rights, (1961), vol. 4, p. 140).

The European Commission, basing itself on the Preamble of the European Convention, further emphasises that 'the purpose of the High Contracting Parties in adopting the Convention was not to grant each other rights and obligations to satisfy their national interests, but to realise the aims and ideals of the Council of Europe... and to establish a common public order of the free democracies of Europe with the aim of safeguarding their common heritage of political traditions, ideas, and the rule of law' (Ibid., p. 138).

One of the most important sources for addressing the theory and practice of human rights obligations comes from the reflections and analyses carried out by the human rights treaty committees that monitor treaty compliance. By examining the work made by each committee once the treaty or the protocol regulating their operation has been ratified, we can also observe the institutional and protective evolution to which I referred at the beginning.

It is important to understand the doctrinal evolution of the Human Rights Committee through its General Comment (hereinafter GC) No. 3 of 1981 and GC No. 31 (2004) on the nature of obligations and which is completed with GC No. 28 on the implementation of the optional protocol. This development also owes much to the International Covenant on Economic, Social and Cultural Rights (hereinafter ICESCR) Committee's GC No. 3 (1990) which laid the foundations in 1990 for overcoming an overly simplistic view of state actions for protecting human rights (such as linking each right to a single obligation primarily identified with state actions of respect or abstention). Thus, the combination of these ideas is perfectly expressed by the Committee on the Rights of the Child in its GC No. 5 on 'General measures of implementation of the Convention on the Rights of the Child (articles 4, 42 and 44, paragraph 6)' of 27 November 2003. General Recommendation No. 28 on article 2 of the Convention on the Elimination of All Forms of Discrimination against Women of 16 December 2010 by the CEDAW Committee is also important.

The analyses made by these committees through their general comments are included in the conclusions of the examinations of the reports of each state, as well as in the examination of cases or communications (inter-state and individual) that the committees make and on which they pronounce through recommendations for individual complainants and for states (since these constitute criteria for challenging the actions of the obligated subjects). 
The doctrinal treatment of human rights obligations, the analysis and decisions adopted by the committees, as well as the judgments of the international human rights courts, provide sufficient elements to describe the features of the obligations to which I will refer. However, I will approach the subject fundamentally from the doctrinal contribution and that of the committees.

\subsection{The objective nature of obligations}

The human rights normative framework has produced norms with a general character and a universal mission. Human rights obligations are objective. As Mègret $(2010,100)$ points out, this objective character is related to the final purpose of the treaties, which is to protect the fundamental rights of people. Mègret underlines the idea that the fulfilment of this purpose is not strictly dependent on the commitments of the parties to the subjective dimension.

Hence, adherence to human rights treaties is best understood if we think of states as making a solemn promise that constitutes an almost unilateral declaration to the international community and individuals within their jurisdictions, as the European Commission of Human Rights confirmed. Mégret (2010) rightly warns that it can only superficially be argued that the basis of human rights obligations lies in the consent or agreement of states.

\subsection{Obligations independent of the principle of reciprocity}

The classical conception of obligations in international law identifies their origin in a relationship of reciprocity in which two or more states are mutually obliged. This conception is expressed by Kelsen $(1943,53)$ as he affirms that most obligations in international law are established through the consent of each state to adhere (or not) to an obligation.

The evolution we have been discussing shows that human rights obligations do not require the principle of reciprocity by other subjects (states) bound by the norms. Their purpose is not to establish reciprocal rights and obligations between states parties, but to establish a system that protects the rights of individuals. A fundamental quality of human rights obligations is that they do not form part of the type of reciprocal obligations arising from a model based on the institution of contract. As Cardona $(2016,140)$ emphasises, the criterion for identifying this type of obligation is mainly formal, rather than dependent on regulating a certain matter - however relevant it may be - precisely because it is conceptualised outside the regime of reciprocity.

The non-reciprocity feature is fundamental in, at least, two relevant matters: firstly, in the interpretation of human rights treaties; and secondly, in the derogation of obligations (as we will see in the following section).

In relation to the first aspect, we start from the idea that human rights treaties are not intended to establish reciprocal rights and obligations between the states parties, but to establish a system to protect human dignity. Therefore the object and purpose of human 
rights treaties and conventions is the protection of the rights of individuals. Article 31 of the Vienna Convention on the Law of Treaties states that: 'A treaty shall be interpreted in good faith in accordance with the ordinary meaning given to the terms of the treaty in their context and in the light of its object and purpose'. Subparagraph 2 furthers explains what should be be understood by the context of a treaty: (a) the text of the treaty, including the preamble and annexes; (b) any agreement relating to the treaty that has been agreed by the parties; and (c) any instrument which was made by one or more parties in connexion with the conclusion of the treaty and accepted by the other parties. By virtue of this provision, Medina $(2005,219-220)$ considers that the rule in article 31 underlines the idea that treaty interpretation must systematically integrate all criteria without any hierarchy between them. The interpretation must consider good faith, the ordinary meaning of the terms, the context of the treaty, and the object and purpose of the treaty. Human rights treaties, unlike other treaties, recognise that individuals have rights with respect to the state and that states have obligations towards individuals. 'Therefore, in interpreting treaties in accordance with their object and purpose, one must be oriented towards the protection of human rights'. Hence, the basic interpretative principle will always be in favour of the individual. Such an interpretation is thus an important feature of the interpretation of human rights norms and a constant guiding principle.

\subsection{Collectively guaranteed obligations}

Human rights treaties recognise rights for individuals (which must be protected) and obligations for states and other subjects (which must be supervised) with validity in both the international and national order (Medina 2005). These are obligations of states towards the international community which, by virtue of their nature, concern all those who are bound by them and are therefore objective legal situations with universal effectiveness that either create or extinguish international obligations.

The obligations establish a 'ought to be' for states and other obligated parties in general. The Human Rights Committee in its GC No. 31 notes that, although article 2 of the ICCPR 'is couched in terms of the obligations of State Parties towards individuals as the right-holders under the Covenant, every State Party has a legal interest in the performance by every other State Party of its obligations'. This expresses the idea of a collective guarantee or collective interest in the protection of rights as: 'rules concerning the basic rights of the human person and as obligations to everyone as indicated in the fourth preambular paragraph of the Covenant... and there is a United Nations Charter obligation to promote universal respect for, and observance of, human rights and fundamental freedoms' (GC No. 31).

The regulated legal interest - human dignity - is a collective interest and the protection of rights is the responsibility of the whole international community (Cardona 2016, 142) and this community has a legal interest in reacting to serious violations. It is in the common interest of the international community to maintain and protect this global public order.

This idea is at the origin of the universal human rights system, which underlines the importance of the aims and objectives of establishing a social and international 
order in which the proclaimed rights and freedoms are made full and effective (art. 28 Universal Declaration of Human Rights), or the Preamble of the ICCPR, which imposes the obligation to promote universal respect for and observance of rights and freedoms. Therefore, all treaties recognise the inter-state communications procedure that enables states to initiate actions to safeguard rights and can so be seen as a manifestation of a legitimate interest of the community.

Rights have a collective guarantee that can be extended and justified in several directions. One of these directions is within the state. As the Committee notes, each state is bound in its entirety and this includes all branches of the state (legislative, executive, and judicial) and at all levels (state, regional, local). This should not be taken for granted, because not all branches of government in a state governed by the rule of law are always fully aware of human rights and consider themselves to be bound by their application in the internal order (HRC, GC 31). This also concerns bodies and institutions that have responsibilities for the protection and realisation of rights with different competences (meaning the multiple levels of law: vertical, horizontal, local, national, and transnational). The legitimacy of such institutions can be analysed by considering the degree to which human rights are part of that institution and the extent to which each contributes or not to articulating recursive relations on the legitimacy of others (Iglesias 2016). It is therefore pertinent to ask what type of relationship and distribution of functions contributes to reinforcing and enhancing the legitimacy of each institution involved in human rights obligations.

\subsection{Obligations arising from mandatory rules}

The Human Rights Committee in GC n' 31 warns that 'rules concerning the basic rights of humans are obligations towards everyone' and this means that these norms bind each state to the international community in the defence and protection of essential collective interests (binding on all states). The collective guarantee is linked to this characteristic and these obligations are also formulated through peremptory norms.

Alarm bells in relation to the principle of jus cogens often ring when this characteristic is pointed out. General international law is based on international custom that requires the consent of states and allows for change through treaties and general principles of law. It is reasonable to consider the importance for international law of jus cogens rules, meaning those that are legally binding and cannot be derogated in accordance with article 53 of the Vienna Convention on the Law of Treaties. Therefore, attempts to determine which norms would be today identified as jus cogens norms are understandable. ${ }^{4}$

However, it can be argued that what in general international law is an exception, the peremptory and non-dispositive character of norms, is the general rule in the case of human rights obligations. In other words, while jus cogens indicates the legal status of

\footnotetext{
${ }^{4}$ The Report of the International Law Commission on 'Fragmentation of International Law' declined to list these norms extensively.
} 
a norm, erga omnes obligations show us the consequences of that status (Zelada 2002, 143). Nevertheless, the reasons that have been offered to support the peremptory character of various norms of general international law can be largely applied to human rights obligations.

The norms that establish human rights obligations are peremptory because they establish conducts, objectives, or results through deontic imperative modalities. Norms can be analytically reconstructed as a statement that links an antecedent, factual assumption, or relevant property with a legal consequence through a deontic or ought-to-be nexus that can have a triple modality (obligatory, prohibited, or permitted). Norms establish that an obligated subject must perform or not perform an action, achieve an objective, or attain a result. Imperative legal norms fulfil a function that can be considered constitutive in legal systems because without imperative norms there is no normative order (Guastini 2016, 67).

Similarly, obligations and prohibitions are conceptualised as guarantees of rights. This perspective, as developed by Ferrajoli (1999, 59-60), has the potential to provide the basis for distinguishing between the recognition of human rights in terms of positive (performance) and negative (non-injury) expectations attributed to a subject by a normative order - and the corresponding duties that are guarantees are also established by legal norms. In turn, Ferrajoli distinguishes between primary guarantees (obligations and prohibitions relating to the subjective right), and secondary guarantees (constituted by the institutionalisation of bodies required to sanction or invalidate violations of primary guarantees). This is what defines for Ferrajoli (1999, 63 ) the 'nomodynamic' structure of modern law as it imposes a distinction between rights and their guarantees by virtue of the recognition of positively existing norms. Human rights in the international order represent a normative order that moves from the recognition of rights to the development and determination of guarantees (that is, a system of human rights protection).

The dispositive character of a legal norm consists of being able to legally escape their binding nature (Miaja de la Muela 1960). But if we consider that norms are formed by the international community and not by the individual will of states who can 'choose' the norms to which they are bound, then norms are not dispositive for member states of the international community in the field of human rights.

\subsection{Obligations towards people - beneficiaries of obligations}

We start from the legal obligation to implement - in good faith - the provisions laid down in international covenants and conventions. This is an obligation towards rightsholders and is key to the demand for state responsibility. This characteristic underlines the importance and leading role of the individual as a subject of rights in the system of rights protection. According to Cançado $(2005,160)$ 'The consolidation of the legal personality and capacity of the individual as subject of international law constitutes the most precious legacy of the international legal thinking of the second half of the 20th century, projecting itself into this beginning of the 21 st century'. 
The perspective of obligations, and not only that of rights, has brought about a change in the position of the individual within the protection system and given the individual a central place in the protection system (Bea 2013, 69). Human rights treaties recognise the rights of individuals and thus took a huge leap forward, since according to classical international law they are not subjects of international law. As Craven $(2000,489,493)$ writes, human rights-holders are not simply incidental beneficiaries of a regime that concerns the promotion of the rights and interests of states. 'The whole new corpus juris of the International Law of Human Rights has been constructed on the imperatives of protection and the superior interests of the human being, irrespectively of his link of nationality or of his political statute, or any other situation or circumstance. Hence the importance assumed, in this new law of protection, by the legal personality of the individual, as subject of both domestic and international law' Cançado $(2005,182)$.

States have obligations towards persons under their jurisdiction, and not only towards those who are citizens of the state. This reaffirms the idea of the universality of human rights and the prohibition of discrimination (HRC, GC 31 §10). 'States Parties are required by article 2, paragraph 1 , to respect and to ensure the Covenant rights to all persons who may be within their territory and to all persons subject to their jurisdiction... The enjoyment of Covenant rights is not limited to citizens of States Parties but must also be available to all individuals, regardless of nationality or statelessness, such as asylum seekers, refugees, migrant workers and other persons, who may find themselves in the territory or subject to the jurisdiction of the State Party'.

Moreover, the leading role of the subject has been reinforced through various processes linked to the protection of rights. This has been assisted firstly by the identification and establishment of obligations to respect, protect, and fulfil human rights, as well as to avoid discrimination; and secondly, by the generalisation of the individual complaint mechanism, which protects the rights of individuals and enables them to file complaints against the state for violations of their rights. This mechanism is expressly accepted by states through the signing and ratification of protocols. Therefore, it seems unreasonable to conclude that the obligations that arise are merely dispositive. As Cançado affirms: 'This is a logical development, as it does not seem reasonable to conceive rights at international level without the corresponding procedural capacity to vindicate them; the individuals are effectively the true complainant party in the international litigation of human rights', (2005, 203).

The growing importance of the role of civil society organisations must also be emphasised. Their participation can be framed in multiple interventions: the production of reports that parallel the ones issued by states; their participation in amicus curiae, and the work of human rights defenders do in preparatory work for new norms 'is symptomatic of the democratisation of international relations, parallel to a growing conscientisation of the multiple subjects of law acting in the contemporary international scenario in favour of universal values. Considering the presence in the contemporary international legal order not only of States and international organisations but also of individuals' (Cançado 2005, 177). 


\subsection{Extension of accountability}

Accountability in relation to the fulfilment and non-fulfilment of human rights obligations has undergone considerable changes. It is primarily a question of an extension of the responsibility of the state, but also extends towards other subjects.

Customary international law establishes that a breach of an international obligation constituting a wrongful act or omission by the state, generates the responsibility of the state and an obligation to make reparation for any material or moral damage caused by the act. We cannot ignore the fact that this is a complex issue, but the principle of accountability has its own profile in the system of human rights protection at different levels, ${ }^{5}$ and I limit myself to highlighting the following:

(a) Human rights obligations are binding on all branches of government (legislative, judicial, and executive) and at all levels (state, regional, and local), and therefore, any agent or authority of the state can incur international responsibility for both action and omission. The Human Rights Committee in its GC 31 states that: 'There may be circumstances in which a failure to ensure Covenant rights as required by article 2 would give rise to violations by States Parties of those rights because of States Parties permitting or failing to take appropriate measures or to exercise due diligence to prevent, punish, investigate, or redress the harm caused by such acts by private persons or entities. States are reminded of the interrelationship between the positive obligations imposed under article 2 and the need to provide effective remedies in the event of breach under article 2, paragraph 3 . The Covenant itself envisages in some articles certain areas where there are positive obligations on States Parties to address the activities of private persons or entities' $(\S 8)$.

(b) The state is also responsible for acts committed by private parties that violate human rights if the state has failed to anticipate the risk of violation by making investigations if necessary or making reparations and providing guarantees of non-repetition.

(c) The UN Committee on Economic, Social and Cultural Rights (CESCR) has established a concept of non-state subjects (NSS) to refer to 'individuals, groups, corporations and other entities, as well as agents acting under their authority', who may have a role and responsibility in the realisation of social rights (CHORNY 2018, 28-29). For example, in relation to the right to work, CESCR includes both private employers and international financial bodies such as the WB, the IMF, and the WTO (CESCR, GC. 18, § 52).

There are also efforts to establish human rights obligations for national and multinational corporations, such as the 'Guiding Principles on Business and Human Rights'. There are various pronouncements by international tribunals regarding the responsibility of international financial organisations regarding the effects of austerity policies on human rights, especially between 2010 and 2019, which must be considered.

\footnotetext{
${ }^{5}$ In this regard, the judgment of the Inter-American Court in the Velásques Rodriguez Case (29 July 1988) is a reference on strict state responsibility for gross human rights violations.
} 
(d) Another area of responsibility arises from the legal obligation to respect, protect, and guarantee rights through cooperation.

Consequently, state responsibility is both direct and indirect. In both cases, there are standards such as due diligence. This principle is breached in those cases, for example, in which an act that violates a right is perpetrated in the absence of any prevention or with impunity; the violation is not investigated; the perpetrator is not prosecuted; the injured party is not compensated; or there are no guarantees of non-repetition. States cannot point to the provisions of their constitutional law or other elements of national law to justify non-compliance or non-application of the obligations undertaken.

To conclude this section, I would like to highlight some of the advantages that the obligations perspective offers in proposing a more comprehensive view of the functions of human rights (Añón: 2018).Obligations express value and respect for human beings. 'The expansion of international legal personality, nowadays encompassing that of individuals as active and passive subjects of international law, goes pari passu with the acknowledgment of accountability in international law. This contributes ultimately to the international rule of law, to the realisation of justice also at international level, thus fulfilling a long-standing aspiration of humankind' (Cançado). It widens the concerns of the global agenda beyond intergovernmental relations and enables a more focused approach to the legitimacy of the obligated subjects and their interactions in influencing the international order. It examines each obligated institution in terms of its (reciprocal) legitimacy, for example between international courts and states, between rights committees and obligated parties; and analyses in what sense the role of the former contributes to strengthening internal rights and vice versa.

The human rights protection system includes institutional control of the obligations in the United Nations through the treaty committees. This is not a subject I can deal with here, but I would like to underline three aspects. Firstly, the legitimacy of the committees and the importance of their existence in relation to the system of rights protection. Secondly, the committees determine the content of the obligations relating to the rights established in each treaty mainly through general comments or recommendations. Thirdly, the committees monitor compliance with the obligations through two channels or procedures: the final observations of the reports presented by the states, and the resolution of interstate and individual complaints or communications. Escobar (2021: 138) redefines these two channels in legal terms as objective and subjective guarantees of rights.

\section{MaintenanCE OBLIGATIONS IN TIMES OF CRISIS}

\subsection{Derogation and limitation of rights}

From a legal point of view and within the normative framework of human rights, times of crisis can be analysed as situations or states of emergency that can be responded to with measures that include derogating or limiting rights and obligations.

It is characteristic of human rights obligations, as I have been arguing, that a violation of human rights by one state does not justify the disappearance of obligations by 
other states. General international law is guided in this regard by the provisions of article 60.1 and 2 of the Vienna Convention, which authorise the termination or derogation of the application of a bilateral or multilateral treaty, in whole or in part, if a serious breach by one of the parties entitles the other party to invoke the breach as grounds for terminating the treaty or derogating its application in whole or in part.

In the field of human rights, however, a different approach is taken. Human rights treaties recognise the possibility of establishing in 'normal situations' justified limitations on rights and allow states to deviate from some of their obligations during a crisis. This is recognised in article 4 of the ICCPR, article 15 of the European Convention on Human Rights, and article 27 of the Inter-American Convention on Human Rights. We also have an authoritative interpretation of article 4 of the ICCPR from the Human Rights Committee in its GC 29 on states of emergency and GC 31. The former on states of emergency (2005) replaced GC 5 (1981) and responded to the UN's concern regarding anti-terrorist policies and the states of emergency declared for this reason.

\section{Article 4}

1. In time of public emergency which threatens the life of the nation and the existence of which is officially proclaimed, the States Parties to the present Covenant may take measures derogating from their obligations under the present Covenant to the extent strictly required by the exigencies of the situation, provided that such measures are not inconsistent with their other obligations under international law and do not involve discrimination solely on the ground of race, colour, sex, language, religion or social origin.

2. No derogation from articles 6, 7, 8 (paragraphs I and 2), 11, 15, 16 and 18 may be made under this provision.

3. Any State Party to the present Covenant availing itself of the right of derogation shall immediately inform the other States Parties to the present Covenant, through the intermediary of the Secretary-General of the United Nations, of the provisions from which it has derogated and of the reasons by which it was actuated. A further communication shall be made, through the same intermediary, on the date on which it terminates such derogation. ${ }^{6}$

From this article 4 and the interpretation given by the Human Rights Committee in GC 29 we can extract the basic requirements in the case of a derogation of obligations:

(a) The first obligation is to formally declare an emergency or serious situation and state the reasons. As a guarantee of this declaration, it must be established through legislation in both a formal and material sense and provide sufficient and accurate

\footnotetext{
${ }^{6}$ The Spanish translation of the Covenant speaks of 'suspensión' of rights, as does the Inter-American Convention on Human Rights, while the English text refers to a derogation.
} 
information on the state's legislation and practice regarding emergency powers $(\S 2)$. As Medina $(2005,257)$ indicates, the state has the power to regulate internationally ratified rights in the national order, but cannot derogate or limit rights, since international law obliges compliance with certain conditions, the absence of which renders the limitation illegitimate.

(b) Obligation to notify the other states parties to the treaty of the content of the declaration. Notification must be accompanied by other safeguards including detailing the measures taken; explaining the reasons for taking the measures; and providing full documentation of the legal provisions ( $\$ \S 2$ y 17).

(c) The cause or reasons.

It must be an exceptional situation that 'endangers the life of the nation'. The Siracusa Principles interpret a threat to the life of the nation when: (a) a situation affects the whole population and all or part of the territory of the state; and (b) it threatens the physical integrity of the population, political independence, or the territorial integrity of the state or the existence or the basic functioning of institutions indispensable for securing and protecting the rights recognised in the Covenant. Accordingly, internal conflict, unrest that does not pose a grave and imminent threat to the life of the nation, or economic difficulties, cannot by themselves justify derogations under article 4 .

(d) Recognition of certain rights and obligations that cannot be derogated. GC 29 refers to this in paragraph 11 by listing the rights that cannot be suspended from articles 6 , 7, 8 (paragraphs I and 2), 11, 15, 16 and 18. In addition, the GC recognises that derogable rights have non-derogable dimensions and the text also sets other limits to derogability (Paragraph 13). Much space is given to procedural guarantees which in their minimum content (access to courts, fair trial, presumption of innocence, and effective remedy) remains in force as an inherent obligation of the Covenant ( $\S \S 14$ and 15). In relation to the ICCPR, derogation clauses have been declared in this pandemic relating to freedom of movement, assembly and association (articles 12, 21, 22), liberty in general, fair trial (articles 9 and 14) and the right to privacy (article 17).

State parties cannot invoke article 4 of the Covenant as a justification for acts that violate humanitarian law or peremptory norms of international law, for example, the taking of hostages, the imposition of collective punishment, arbitrary deprivation of liberty, or disregard for fundamental principles of fair trial, and in particular, the presumption of innocence $(\S 11)$.

\section{(e) Prohibition of discrimination (paragraph 8)}

Derogation from obligations and rights is only justified in public emergencies that threaten the life of the nation and the existence of which is officially proclaimed, the states parties to the present Covenant may take measures derogating their obligations under the present Covenant to the extent strictly required by the demands of the situation, providing that such measures are not inconsistent with their other obligations under international law 
and do not involve discrimination on the grounds of race, colour, sex, language, religion, or social origin, as well as discrimination unjustifiably affecting some groups and not others. Non-nationals are not recognised, but GC 31 does recognise these groups.

(d) Proportionality of the measures.

The principle proposed is that all exceptions require a more demanding test of proportionality than is accepted as a limitation in normal times because there are risks of violating the essential content of all these rights. However, the GC points out that in the case of freedoms the parameters of rationality are applied to the limitations, and the proportionality criterion that is applied is the same for limitations of rights and derogations. This constitutes an argument for the relativity of the difference between the two legal categories.

In summary, GC 29 offers a series of principles that can be expressed in various ways but which prohibit affecting non-derogable obligations in accordance with other international norms, as well as the prohibition of discrimination, limitations that guarantee the principle of legality and the rule of law as necessary in a democratic society (a criterion on which the European Court of Human Rights has expanded), ${ }^{7}$ the requirement for proportionality of measures linked to respect for the essential content of rights, and judicial (internal) as well as treaty body (external) control of limitations.

We can now connect these precedents with the current pandemic crisis. The GC lists international law obligations that always remain in force and refers to other documents such as the Siracusa Principles on the limitation and derogation of the International Covenant on Economic, Social, and Cultural Rights (UN Economic and Social Council 24 August 1984).

I noted initially that the state's response to certain situations may be to derogate rights and obligations or to limit them. However, the distinction is not so clear-cut. The GC states that derogation is clearly distinct from limitations of human rights but does not indicate differences between these concepts.

The concept of 'derogation' as Escobar $(2021: 137,146)$ argues is not a distinct and clearly distinguishable legal concept from that of limitation of rights. This is an issue that has arisen in the context of the Covid-19 pandemic and declarations of states of emergency or similar.

\footnotetext{
7 The expression 'necessary in a democratic society' has been broadly interpreted by the European Court of Human Rights 132 (van Dijk and van Hoof 2018, 307-335) and a similar interpretation has been given by the Inter-American Court of Human Rights, which, in its Advisory Opinion 5/85, drew a parallel with European jurisprudence and incorporated it into the system. The Inter-American Court held that in the Inter-American system the limitation: (i) must respond to the 'existence of a compelling social need', that is, it must be oriented 'to satisfy an imperative public interest'; (ii) among several options to achieve this objective 'the one that restricts on the smallest scale the protected right must be chosen'; and (iii) the limitation must be 'proportionate to the interest that justifies it and closely adjusted to the achievement of that legitimate objective' 133. In summary, the court evaluates measures through the lens of proportionality.
} 
The GC does not indicate differences between derogation and limitation - but states that the principle of proportionality applies to both. In paragraph 4: 'Derogation from some Covenant obligations in emergency situations is clearly distinct from limitations allowed even in normal times under several provisions of the Covenant. Nevertheless, the obligation to limit any derogations to those strictly required by the exigencies of the situation reflects the principle of proportionality which is common to derogation and limitation powers. Moreover, the mere fact that a permissible derogation from a specific provision may, of itself, be justified by the exigencies of the situation does not obviate the requirement that specific measures taken pursuant to the derogation must also be shown to be required by the exigencies of the situation. In practice, this will ensure that no provision of the Covenant, however validly derogated, will be entirely inapplicable to the behaviour of a State party'.

It does not seem reasonable to interpret the derogation of rights as a suppression of those rights, which would constitute, as Rubio states (2020), an infringement with or without a state of emergency. Nor can it mean that rights are 'deconstitutionalised' and Escobar points out that the derogation of a right would be equivalent to a limitation, as the same model of control of the latter is defended, namely: legal provision; essential content; limits; and the principle of proportionality (2021).

With the outbreak of Covid-19, the Human Rights Committee drafted a Statement on derogations from the Covenant in connection with the Covid-19 pandemic, CCPR/C/128/2, 30 April 2020. As Escobar (2021: 140) discusses, this statement basically repeats the doctrine established in GC 29, although emphasising some more novel aspects. The general rule is that public health problems must be addressed with instruments that are appropriate for normal situations, and therefore although rights may be limited, derogation measures should be resorted to only when this is not possible. The aim of the measures is a return to normality. Moreover, as Escobar warns in support of his thesis, there is no significant difference between a derogation and a limitation of rights, and the above declaration states in paragraph c: 'States parties should not derogate from Covenant rights or rely on a derogation made when they are able to attain their public health or other public policy objectives by invoking the possibility to limit certain rights, such as article 12 (freedom of movement), article 19 (freedom of expression) or article 21(right to peaceful assembly), in conformity with the provisions for such limitations set out in the Covenant, or by invoking the possibility of introducing reasonable limitations on certain rights, such as article 9 (right to personal liberty) and article 17 (right to privacy), in accordance with their provisions'.

Both at international and national levels, there have been interesting debates on the derogation or limitation of rights following a declaration of a state of emergency. Regarding the application of the derogation clause in article 4 of the ICCPR, Scheinin, who was UN Special Rapporteur (2005-2011) and for eight years a member of the UN Human Rights Committee and participated in the drafting of the Committee's GC 29 on states of emergency in 2001, made several observations. In his opinion (2020) after the events of 9/11, this document proved useful to maintain control over anti-terrorist measures that violated human rights. In his view and considering the risk of abuse 
(such as curtailing dissent, dissolving parliament, postponing elections, consolidating the powers of would-be dictators, and consolidating powers of the executive over the legislature) affecting the right to due process or invasion of privacy by unlimited control, the safest course of action is to insist on the principle of normality: namely, managing a crisis with normal powers and procedures and insisting on full compliance with human rights. ${ }^{8}$

Therefore, rather than declaring states of emergency as a response to the pandemic, he proposes insisting on the principle of normality. This can be achieved by establishing the necessary and proportionate limits on human rights because of a pressing social need created by the pandemic. Green (2020) advocates the application of article 4 of the ICCPR and considers that the derogative clause provides guarantees. The declaration of a state of emergency, the derogation of certain specific obligations, and the requirement for international notification seems to him to be adequate for the situation. Medina also values the notification as further proof of the global public order to which we have referred. Another guarantee is the power of the international supervisory bodies to control whether a declaration of emergency and the specific measures taken on its basis do not infringe the Treaty. Conversely, Green argues, it is the failure to make use of this option that may risk normalising exceptional powers and permanently recalibrating human rights protections downwards. If the exigencies of the pandemic require exceptional measures and the diversion of some dimensions of the full enjoyment of all human rights, then the most consistent approach is to introduce those measures through a framework that implies a commitment to legality and the full restoration of normality as soon as possible. Notification can be seen as further evidence of the existence of a global public order that gives states parties the right to react to the conduct of any state that compromises the stability of the system (Medina 2005, 269-270). International supervisory bodies also have the power to control whether the declaration of emergency and the measures taken on its basis do not violate the Treaty.

Escobar $(2021,150)$ argues that we have sufficient elements to indicate that the difference between limitation (limitation or affectation) of rights and derogation is subtle. Derogation may mean a 'more intense limitation'. In support of this thesis, he puts forward the following arguments. (a) The distinction regarding the grounds for derogation (serious threat to the life of the nation) and limitation (public order, national security, public health, etc.) may seem clear - but there is no substantial difference in practice.

\footnotetext{
${ }^{8}$ Nearly 20 states parties to the three treaties mentioned above have resorted to derogation during the current Covid-19 epidemic by officially declaring it a life-threatening state of emergency, and so notifying the United Nations, the Organisation of American States, or the Council of Europe of the unilateral abrogation of some of their obligations under the three treaties. As of 2 April 2020, these included eight countries abrogating the ECHR (Albania, Armenia, Estonia, Georgia, Latvia, Latvia, Moldova, North Macedonia, and Romania), three of them notably EU Member States, as well as ten Latin American countries (Argentina, Bolivia, Chile, Colombia, Ecuador, El Salvador, Guatemala, Honduras, Panama, and Peru) abrogating the ACHR. A subset of six of these states have also notified the UN of derogations from the ICCPR (Armenia, Ecuador, Estonia, Guatemala, Latvia, and Romania). The sheer volume of Covid-19 derogations - almost one in ten nations worldwide - is unprecedented.
} 
Firstly, because it must be proven; and secondly, because the arguments ultimately come back to national security, public order, and public health. (b) In the case of derogation, the rights affected are specific, whereas limitation can affect all rights. Escobar argues that this difference is irrelevant because respect for the essential content must always be maintained despite derogation (Añon 2016, 66-74). Moreover, as we have seen in the case of freedoms, the reasoning associated with limitation is also applied. Finally, (c) there is no great difference between declaring a derogation or not. In conclusion, the derogative clause constitutes, for Escobar $(2021,150)$, a generic authorisation to limit rights that is outside the usual forms and procedures - and therefore fulfils an important function of reinforcing guarantees, for example, regarding executive power in exceptional situations. In agreement, Scheinin explains that the scope of legitimate additional measures affecting human rights is rather limited. Countries that have abused emergency powers to seize power have not applied the derogation clause because they do not wish to be limited by the framework of official derogation. Alan Greene is therefore correct in stating that international notification of an emergency can reflect a country's commitment to legality and normality.

This is a debate that has also taken place nationally given that the type of 'limitations' that were put in place during the pandemic necessitated the declaration of some type of state of emergency, although the justifying argument is based on an emergency that is endangering the health of entire nations and is therefore a justification for the limitation of rights.

\subsection{Prohibition of regressivity}

Civil rights and social rights share obligations clearly set out in article 2 of the ICCPR and article 2 of the ICESCR. These shared obligations partially account for the continuity of civil and social rights (this thesis is held by many - including Courtis and Abramovich, 2002). ${ }^{9}$ However, it must be acknowledged that the Covenant on Economic, Social and Cultural Rights does not contain any derogative clause analogous to article 4 of the Covenant on Civil and Political Rights.

\footnotetext{
${ }^{9}$ The Committee on the Rights of the Child expresses the continuum between civil and political rights extremely well in its Comment No. 5 on treaty obligations. Paragraph 6 states: article 4, while reflecting the general obligation of States Parties regarding implementation, draws in its second sentence a distinction between civil and political rights, and, on the other hand, economic, social, and cultural rights. 'With respect to economic, social, and cultural rights, States Parties shall undertake such measures to the maximum extent of their available resources, and where needed, within the framework of international cooperation'. There is no simple or credible division of human rights in general, or of the rights recognised by the Convention in particular, into these two categories of rights. The Committee's reporting guidelines group articles 7, 8 , 13-17 and 37(a) under 'civil rights and freedoms', but the context indicates that these are not the only civil and political rights recognised in the Convention. Indeed, many other articles, including articles 2, 3, 6 and 12 of the Convention, contain elements that constitute civil or political rights, reflecting the interdependence and indivisibility of all human rights. The enjoyment of economic, social, and cultural rights is inextricably linked to the enjoyment of civil and political rights. As noted in paragraph 25 below, the Committee believes that the justiciability of economic, social, and cultural rights, as well as civil and political rights, must be recognised.
} 
The obligations common to all rights include the obligation to take immediate measures, as well as the obligations to respect, protect, guarantee, and recognise rights while establishing primary and secondary guarantees. These include comprehensive obligations: non-discrimination, and respect for the minimum of human rights (Añon 2018). Article 2 of the ICESCR establishes the obligation of progressivity within the limit of available resources, and states that essential levels of rights must be maintained during a crisis or recession and that vulnerable groups must always have their rights guaranteed. Is this an obligation that only affects social rights? Not at all, the pandemic highlighted something that the Special Rapporteur on severe poverty had already denounced in his 2017 report on poverty and civil rights. But it is true that one of the basic guarantees for the full effectiveness of social rights is the obligation of progressivity - whereby a right is achieved within a reasonable period and then gradually enhanced. This means the prohibition of regression.

It is important to focus on obligations and their maintenance and even reinforcement in times of crisis, such as armed conflicts, natural disasters, socio-economic crises, or a global pandemic. It is also important to assess the impact of the rules for dealing with Covid-19 on the basis of human rights obligations and evaluate whether we are facing violations regarding, for example, the right to an adequate standard of living, food, housing in its various dimensions, and healthcare.

During the 2007 economic crisis and the subsequent decade of social crisis, no nation declared a state of emergency and civil rights were not formally derogated. However, regressive measures on social and civil rights were adopted as a direct result of the adoption of austerity. The effects of austerity policies on human rights in the universal human rights protection system ${ }^{10}$ and regional human rights protection systems have been studied by many international and academic organisations (Ginsborg 2017). Jurisprudence from the European Court of Human Rights and the European Committee of Social Rights examines, although not always clearly, the degree of state autonomy in the context of austerity and the degree of responsibility for human rights violations resulting from these measures that can be directly attributed to those organisations that advocated austerity. These developments are analysed in the light of international human rights law, as well as international institutional law. ${ }^{11}$

The implementation of these measures had a global impact and a significant weakening of public protection systems. The Special Rapporteur on severe poverty, when

\footnotetext{
${ }^{10}$ For example, Ortiz et al. 2015, CERS 2018.

${ }^{11}$ Austerity measures have damaged a range of human rights, both directly and indirectly, through negative economic impacts. They have undermined rights to education, food, health, and housing, and rights to decent work, fair wages, and social security; as well as freedom of expression and rights to life and personal security. Austerity has exacerbated disparities such as income, gender, race, age, disability, and migration status. The social and economic effects of austerity are combined with deepening political inequalities. The lack of voice and political power of the most disadvantaged in society contributes to their invisibility in the eyes of policymakers charged with designing adjustments. Unsurprisingly, the disproportionate costs they bear are often hidden. FRA 2013, OIT 2017, CERS 2018.
} 
analysing the impact of measures introduced after the Covid-19 pandemic was declared, described it as 'the worst economic crisis since the Great Depression'.${ }^{12}$ This is a crisis that cannot be understood in isolation from the previous crisis and in which it has its roots. Ten years on, the rapporteur notes, the legacy of the previous crisis is marked by 'entrenched inequalities, intractable poverty and public services in a sad state of disrepair' (\$51). The impact of austerity on public services - now considered essential - has persisted and this has consequences for human rights around the world (§52). As a result, the state of socioeconomic rights that was already in dire straits when the pandemic broke out has led to a deterioration in public health systems ( 553$)$. Care work has been undervalued and made precarious although much of it is carried out by newly termed 'essential workers' ( $\$ 55)$. Social services around the world are severely underfunded and overburdened by demands that must be processed very quickly and where outsourcing can be seen as an abdication of governmental responsibility ( 556$)$. Extreme inequality is coupled with great wealth, excessive profits (§57), a worldwide reduction of corporate tax rates (§58), increased working hours, and a pauperisation of employment or increased precariousness.

The period from 2008 to 2019 was of great concern to the United Nations. The 2017 report by the independent expert Pablo Bohoslavsky diagnosed the crisis and showed how the austerity measures adopted had negative impacts on human rights, and the extent to which states have failed to meet their obligations. This report is at the origin of a statement of guiding principles for assessing these policies and identifying and systematising existing human rights obligations and setting principles on how to assess the consequences of anticrisis measures on human rights. ${ }^{13}$

In the 'Guiding Principles on Human Rights Impact Assessments of Economic Reforms' the UN General Assembly urges states to either act on their own or as members of international financial institutions and adopt economic policies that ensure that human rights are respected, protected, and fulfilled (Principle 2, UN General Assembly, 2018). Principle 3 on the burden of proof states that this implies a duty to make human rights impact assessments address the human rights impacts of their economic policies. These assessments should be made before and after and should also, among other issues, 'Demonstrate how the proposed measures, together with other economic measures and policies being implemented or to be implemented, could affect the human rights of the population, and especially the most marginalised or at-risk individuals and groups' (Principle 17).

We assume that the obligation of progressivity and the prohibition of retrogression are guarantees of rights. Accordingly, it is a matter of identifying any prima facie retrogressive measures, as well as alternative economic policy options that may be the least restrictive to human rights and avoid any proscribed retrogression'. Thus, states

\footnotetext{
${ }^{12}$ The Special Rapporteur on extreme poverty and human rights: Looking Back to Look Ahead: A RightsBased Approach to Social Protection in The Post-Covid-19 Economic Recovery, 11 September 2020.

${ }^{13}$ General Assembly: Guiding Principles on Human Rights Impact Assessments. Report of the Independent expert on the effects of foreign debt and other related international financial obligations of States on the full enjoyment of all human rights, particularly economic, social, and cultural rights. A/HRC/40/57, 19 December 2018.
} 
legitimately enjoy a margin of discretion in the design of their own policies (for example, fiscal policies). However, this discretion is limited. The ICESCR recognises the possibility of 'limitations on rights that are determined by law to the extent that they are compatible with the nature of these rights and solely for the purpose of promoting the general welfare in a democratic society' (art. 4) as part of national legislation that is generally applicable, clear, and accessible to all.

When a measure that limits rights is adopted, there is a presumption of noncompliance by ICESCR (Committee on ESC rights, GC No. 3). According to the Committee on Economic, Social and Cultural Rights (CESCR Committee) the state must justify the adoption of the measure based on a series of elements.

Treaty committees, other treaty bodies, regional human rights bodies, and national courts have developed various criteria for making assessments on the basis on which retrogressive measures might be legally justified. For its part, the Committee on Economic, Social and Cultural Rights (CESCR) has developed a set of principles for assessing retrogressive measures which, in part, stems from an examination of the parameters of justification of limitations of rights. The committee's reasoning is based on the rationality and proportionality that national courts follow in a mostly standardised way in the national legal systems. This process culminated in the GC on social security, which embodied these criteria.

This set of criteria and guidelines is reflected in a document on the guiding principles on human rights impact assessments, which devotes Principle 10 to the prohibition of retrogression. The document states that any economic reform proposal that leads to a regression in the realisation of economic, social, and cultural rights is considered a violation of those rights. Thus, measures that would lead to retrogression in the realisation of these rights are permissible only if states can demonstrate that such retrogressive measures are:

a) temporary in nature and effect - and limited to the duration of the crisis;

b) legitimate and intended to protect all human rights. According to article 4 of the ICESCR, limitations on rights shall be solely for promoting the general welfare in a democratic society. Furthermore, according to the CESCR, the measure must be duly justified by reference to all the rights in the Covenant;

c) reasonable in that the means chosen are the most appropriate for achieving the legitimate aim. The CESCR has defined criteria that it considers in determining the reasonableness of measures adopted by a state. The measures must be 'deliberate, specific, and aimed at the fulfilment of economic, social and cultural rights', as well as non-arbitrary, non-discriminatory, and must consider 'the precarious situation of disadvantaged and marginalised individuals or groups';

d) necessary in that the adoption of any other policy alternative or inaction would be more detrimental to the enjoyment of economic, social, and cultural rights, especially if alternative and less harmful financing mechanisms are available. In the words of CESCR 
it means that 'the adoption of any other policy alternative, or inaction, would be even more detrimental to the realisation of human rights';

e) proportionate in that the measures do not unduly limit human rights. The measures chosen must be within certain substantive and procedural limits;

f) non-discriminatory and able to prevent or mitigate inequalities that may arise during a crisis, as well as ensuring that the rights of disadvantaged and marginalised individuals and groups are not disproportionately affected. Human rights impact assessments of economic reforms must consider the direct and indirect discriminatory impact of economic reform policies on the most disadvantaged (Principle 7).

g) protect the minimum content of economic, social, and cultural rights. This recognition is fundamental as a guarantee of social rights and as an anchor of the reasoning applied to rollbacks and limits to rights (as already emphasised);

h) require a high level of transparency as an evaluative and monitoring principle and the genuine participation of affected groups in the examination of proposed measures and alternatives;

i) subject to meaningful review and accountability (including human rights impacts).

Among the criteria for assessing limiting measures, the principles that constitute proportionality in a broad sense are considered. The legitimate aim of the measure is examined in accordance with the object and purpose of the treaty, the need for the measure, its suitability or rationality, and its proportionality. The temporary and exceptional nature of the measure must also be assessed.

The criteria of temporariness and exceptionality are linked to the principle of proportionality. Taken together, they aim to ensure that a derogation of rights or a regression occurs to the extent and for the period that is strictly necessary. If the situation justifies such measures, writes Medina (2016: 266), international standards imply that the measures must be proportional in time and form, and conducive to the objective of overcoming the emergency. This requirement applies both to a general measure limiting a right and to each of the measures that an authority adopts in application of the general measure. These limits point to two aspects: the way rights are affected and the persons who will be affected (Medina 2005: 67). Regarding the former, the measures must not be too extensive and should constitute the ideal and only means to re-establish normality. Regarding the persons affected, the authority must limit itself to derogating the rights of those who are directly involved in the emergency, without affecting the rights of others who are not affected.

The temporary and limited nature of the measures has not been questioned so far, given that it is a response to a crisis or state of emergency. However, in the situation generated by the pandemic we have seen that the measures must address structural situations arising from a decade of weakening social protection systems. These temporary and exceptional measures address dimensions of the law that the pandemic has put at greater risk and 
that need to be reinforced by structural measures. As the Special Rapporteur on Severe Poverty $(2020, \S 75)$ argues: 'The world was ill-prepared to cope with this pandemic, but it need not have been. Building social protection systems based on human rights can contribute significantly to effectiveness in eradicating poverty and reducing inequalities and will make societies more resilient to crises. This means defining social protection not as an emergency response to a crisis, nor as charity'.

When evaluating measures, we must consider their limits, which are marked by criteria such as compatibility with other obligations. Most significantly, the prohibition of discrimination plays a key role when assessing the effects of pandemic measures.

We must also consider criteria relating to the process of adopting measures: the principle of legality, as well as guarantees of participation and accountability. It is now a general principle that the implementation of human rights treaties requires each state party to be accountable to its citizens and other members of the community at national and international levels. For this accountability to work effectively, appropriate mechanisms and institutions must be established (CEDAW, GR 28, §§39-40).

\section{ConCluding Notes}

Human rights obligations understood as objective obligations that are derived from peremptory norms whose guarantor is the international community, have progressed in identifying human rights violations and adopting protective legal measures. Therefore, they contribute to the ongoing construction of a universal system for the protection of rights.

The elements explaining the evolution of these obligations reinforce their binding nature and the position of human beings as a subject of rights and a beneficiary of obligations as well as extending the responsibility of obliged subjects.

These characteristics are especially relevant in times of universal crises such as the Covid-19 pandemic. Human rights obligations constitute a standard for examining the impact of the norms for dealing with the pandemic and deciding if human rights are being violated. Although responses to the pandemic have been nationally driven, human rights obligations are safeguards for monitoring the derogation of such obligations.

Simultaneously, with progress in the identification of obligations, criteria have been set to evaluate regressive or rights-limiting measures. These criteria are applicable to measures that address the pandemic and constitute broad criteria for assessing measures from various approaches: (a) proportionality in a broad sense; (b) the effects of the measures, especially if they are discriminatory; (c) the limits of the measures; (d) the adoption process and its guarantees: participation, transparency, and accountability.

Human rights responses to this crisis cannot be based on emergency, temporary, or exceptional measures, but must be based on sustained, structural, and fundamental measures. The lesson to be learnt is that human rights obligations should not be derogated in times of pandemic. 


\section{BibLIOGRAPHICAL REFERENCES}

ABRAMOVICH, Víctor, Christian COURTIS (2002), Los derechos sociales como derechos exigibles, Madrid, Trotta.

AMERICAN ASSOCIATION FOR THE INTERNATIONAL COMMISSION OF JURISTS (1985) 'Siracusa Principles. on the Limitation and Derogation Provisions in the International Covenant on Civil and Political Rights' https://www.icj.org/ wp-content/uploads/1984/07/Siracusa-principles-ICCPR-legal-submission-1985eng.pdf. [Accessed 10 April 2021].

AÑÓN, María José (2018) “Derechos humanos y deberes: efectividad y prohibición de regresividad", Repensar los derechos humanos, A. Ródenas (ed), Lina, Palestra, pp. 263-306.

AÑON, María José (2016) ‘¿Hay límites a la regresividad de los derechos humanos?’, Derechos y Libertades, Número 34, Época II, enero 2016, pp. 57-90. DOI: $10.14679 / 1020$

BEA Emilia (2013), Conversación con Antônio Augusto Cançado Trindade. Reflexiones sobre la Justicia Internacional, Valencia, Tirant Lo Blanch.

BOHOSLAVSKY Pablo (2017) 'Report of the Independent Expert on the effects of foreign debt and other related international financial obligations of States on the full enjoyment of all human rights, particularly economic, social and cultural rights, including economic, social and cultural rights of all human rights, particularly economic, social and cultural rights. Elaboration of guiding principles for assessing the impact of the impact of economic reform policies on human rights human rights,' A/HRC/37/54, 20 de December de 2017.

CANÇADO TRINDADE, Antônio (2005) 'The emancipation of the individual from his own state: the historical recovery of the human person as subject of the law of nations', La Corte interamericana de derechos humanos: un cuarto de siglo, Publicaciones Corte Interamericana, pp. 159-206.

CARDONA, J. (2016), «Hacia la configuración de un «sistema» de protección de los derechos humanos de Naciones Unidas», Cursos de derecho internacional y relaciones internacionales de Vitoria-gasteiz, 2016/1, pp. 135-172

CCPR Human Rights Committee (2001) General Comment No 29, 'Derogations during State of Emergency', CCPR/C/21/Rev.1/Add.11, 31 August 2001.

CCPR Human Rights Committee (2004) General Comment $N^{\circ} 31$, 'The Nature of the general legal obligations imposed on States Parties to the Covenant', CCPR/C/21/ Rev.1/Add.13, 26 May 2004

CCPR Human Rights Committee (2020) 'Statement on derogations from the Covenant in connection with the COVID-19 pandemic', CCPR/C/128/2 (24 April 2020)

CEDAW Committee on the Elimination of Discrimination against Women (2010) General recommendation No. 28 'On the core obligations of States parties under article 
2 of the Convention on the Elimination of All Forms of Discrimination against Women' CEDAW/C/GC/28, 16 December 2010

CENTER FOR ECONOMIC AND SOCIAL RIGHTS (CERS) (2018) Assessing Austerity. Monitoring the Human Rights Impacts of Fiscal Consolidation. BRIEFING. February 2018

CESCR Committee on Economic, Social and Cultural Rights (1990) General Comment No. 3 'The Nature of States Parties' Obligations (Art. 2, Para. 1, of the Covenant), (Contained in document E/1991/23),14 December 1990

CESCR Committee on Economic, Social and Cultural Rights (2008) General Comment No. 19 'The Right to Social Security” E/C.12/GC/19, Å42, 4 February 2008.

CHORNY ELIZALDE, Vladimir (2018) 'La violación de derechos humanos por sujetos no estatales: una visión completa de los derechos', Revista latinoamericana de Filosofía Política, vol VII/1, pp. 1-46.

CORTE INTERAMERICANA DE DERECHOS HUMANOS Opinión consultiva OC2/82 del 24 de setiembre de 1982 el efecto de las reservas sobre la entrada en vigencia de la Convención americana sobre derechos humanos

CRAVEN, Matthew, (2000) 'Legal Differentiation and the Concept of the Human Rights Treaty International Law, 11 European Journal of International Law, 2000/3, pp. 489-519. https://doi.org/10.1093/ejil/11.3.489

CRC Committee Rights to the Child (2003) General Comment No. 5 'General Measures of Implementation of the Convention on the Rights of the Child', CRC/GC/2003/5, 27 November 2003

ESCOBAR ROCA, GUILLERMO (2021) 'Los derechos humanos en estados excepcionales y el concepto de suspensión de derechos fundamentales', Revista de Derecho Político, no 110, enero-abril 2021, pp. 113-152. https://doi.org/10.5944/ rdp.110.2021.30330

EUROPEAN UNION AGENCY FOR FUNDAMENTAL RIGHTS (FRA), 2013. 'The European Union as a community of values: Safeguarding fundamental rights in times of crisis" at: http://fra.europa.eu/en/publication/2013/europeanunioncommunity-values-safeguarding-fundamental-rights-times-crisis. [Accessed 15 May 2021].

FERRAJOLI, Luigi (1999), Derechos y garantías. La ley del más débil, Madrid, Trotta, Prologo P. Andrés Ibañez, Traducción P. A. Ibañez y A. Grepi.

FRASER, Nancy (2008) Scales of Justice. Reimagining Political Space in a Globalizing World, Columbia University Press

GINSBORG, L. (2017) 'The impact of the economic crisis on human rights in Europe and the accountability of International Institutions' (2017) 1 Global Campus Human Rights Journal 97-117 
GREEN, Alan (2020) 'Derogating from the European Convention on Human Rights in Response to the Coronavirus Pandemic: If not Now, When?', European Human Rights Law Review. https://doi.org/10.2139/ssrn.3593358

GUASTINI, R. (2016) La sintaxis del derecho, Marcial Pons, Madrid, traducción de Álvaro Nuñez.

IGLESIAS, Marisa (2016), ‘LLos derechos humanos como derechos especiales? Algunas ventajas de una concepción cooperativa de los derechos humanos', Anuario de Filosofía del Derecho, 2016 (XXXII), pp. 119-144.

INTERNATIONAL LABOUR ORGANIZATION (ILO), 2017. "World Social Protection Report 2017-19: Universal social protection to achieve the Sustainable Development Goals" at http://www.ilo.org/wcmsp5/groups/public/---dgreports/--dcomm/---publ/documents/publication/wcms_604882.pdf. [Accessed: 10 May 2021].

INTERNATIONAL LAW COMMISSION (2006) Fragmentation of international law: difficulties arising from the diversification and expansion of international law Report of the Study Group of the International Law Commission Finalized by Martti Koskenniemi A/CN.4/L.682 13 April 2006. https://doi.org/10.1016/j. arcped.2006.03.063

KELSEN, Hans (1943) Derecho y paz en las relaciones internacionales México, Fondo de Cultura Económica traducción F. Acosta.

LAFONT Cristina (2020) 'Are human rights associative rights? The debate between humanist and political conceptions of human rights revisited,' Critical Review of International Social and Political Philosophy, https://doi.org/10.1080/13698230. 2020.1859221

MEDINA, Cecilia (2005), 'Las obligaciones de los Estados bajo la Convención americana sobre derechos humanos', La Corte interamericana de derechos humanos: un cuarto de siglo, Publicaciones Corte Interamericana, pp. 209-270.

MÈGRET Fréderic (2010) 'Nature of Obligations', International Human Rights Law / ed. by Daniel Moeckli, Sangetta Shah, Sandesh Sivakumarian, Oxford, Oxford University Press, pp. 97-118.

MIAJA DE LA MUELA, Adolfo. (1960) 'Ius cogens y ius dispositivum en Derecho Internacional Público'. Libro homenaje al profesor Luis Legaz y Lacambra. Santiago de Compostela: Tecnos, tomo 11.

ORTIZ Isabel, Matthew CUMMINS Jeronim CAPALDO Kalaivani KARUNANETHY, (2015) 'The decade of adjustment: a review of austerity trends 2010-2020 in 187 countries', Extension of Social Security Working Paper núm. 53 (Ginebra, OIT) At http://www.social-protection.org/gimi/gess/RessourcePDF.action?ressource. ressourceId=53192. https://doi.org/10.2139/ssrn.2685853. [Accessed: 20 February 2021]. 
PEZZANO, L. (2014) «Las obligaciones de los Estados en el sistema universal de protección de los derechos humanos», Anuario español de Derecho Internacional, vol. 30, pp. 303-346

RUBIO Ruth, (2020): 'España y el Convenio Europeo de Derechos Humanos en tiempos de pandemia: posibilidades y límites', ElDiario.es https://www.eldiario.es/andalucia/ desdeelsur/espana-convenio-europeo-derechos-humanos_132_5956586.html. [Accessed: 7 May 2020].

SCHEININ, Martin (2020) 'Covid-19 Symposium: To Derogate or Not to Derogate?' Opinio Iuris Blog, 6 april 2020. http://opiniojuris.org/2020/04/06/covid-19symposium-to-derogate-or-not-to-derogate/. [Accessed: 6 April 2020].

UN General Assembly (2018) 'Guiding principles on human rights impact assessments of economic reforms Report of the Independent Expert on the effects of foreign debt and other related international financial obligations of States on the full enjoyment of human rights, particularly economic, social and cultural rights' A/HRC/40/57, 19 December 2018

UN Special Rapporteur on Extreme Poverty and Human Rights, (2020) 'Looking back to look ahead: A rights-based approach to social protection in the post-COVID-19 economic recovery', 11 september 2020

VAN DIJK, Pieter; VAN HOOF, Fried and VAN RIJN, Arjen (2018) Theory and Practice of The European Convention on Human Rights, Intersentia, $5^{\text {th }}$ edition, pp. 307-335

ZELADA, Carlos (2002) 'Ius Cogens y Derechos Humanos: Luces y sombras para una adecuada delimitación de conceptos', Agenda internacional, № 17, 2002, PP. $129-156$ 